\title{
Jounal of Diabetes
}

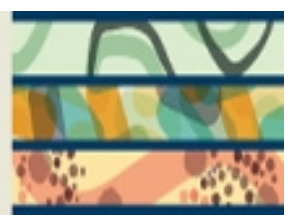

\section{Does undiagnosed diabetes mitigate the association between diabetes and cognitive impairment? Findings from the ELSI-Brazil study}

\begin{tabular}{|r|l|}
\hline Journal: & Journal of Diabetes \\
\hline Manuscript ID & JDB-2019-485.R1 \\
\hline Danuscript Type: & Original Article \\
\hline Author: & n/a \\
\hline Complete List of Authors: & $\begin{array}{l}\text { Cochar-Soares, Natália; Federal University of Sao Carlos, Department of } \\
\text { Gerontology } \\
\text { de Carvalho, Danilo; Federal University of Sao Carlos, Graduate Program } \\
\text { in Physical Therapy } \\
\text { de Andrade, Fabíola; Oswaldo Cruz Foundation, René Rachou Research } \\
\text { Center } \\
\text { Castro-Costa, Erico; Oswaldo Cruz Foundation, René Rachou Research } \\
\text { Center } \\
\text { de Oliveira, Cesar; University College London, Department of } \\
\text { Epidemiology and Public Health } \\
\text { Lima-Costa, Maria Fernanda; Oswaldo Cruz Foundation, René Rachou } \\
\text { Research Center } \\
\text { Alexandre, Tiago; Federal University of Sao Carlos, Department of } \\
\text { Gerontology }\end{array}$ \\
\hline Scope of Manuscript: & Aging < Diabetes, Type 2 Diabetes < Diabetes \\
\hline Keywords: & Aging, Cognitive Impairment, Diabetes Mellitus \\
\hline
\end{tabular}


Does undiagnosed diabetes mitigate the association between diabetes and cognitive impairment? Findings from the ELSI-Brazil study

\author{
Diabetes Mellitus and Cognitive Function
}

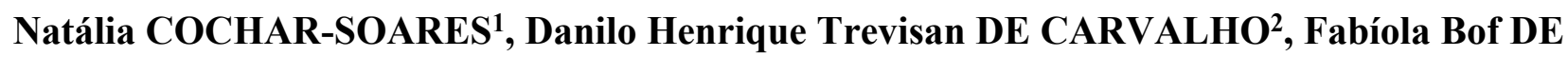 \\ ANDRADE ${ }^{3}$, Erico CASTRO-COSTA ${ }^{3}$, Cesar DE OLIVEIRA ${ }^{4}$, Maria Fernanda LIMA-COSTA ${ }^{3}$, \\ Tiago da Silva ALEXANDRE, 1,2,
}

\begin{abstract}
Affiliations:
1 - Graduate student, Department of Gerontology - Federal University of Sao Carlos, Sao Carlos, Brazil 2 - MSc, Graduate Program in Physical Therapy - Federal University of Sao Carlos, Sao Carlos, Brazil 3 - PhD, René Rachou Research Center - Oswaldo Cruz Foundation

4 - PhD, Department of Epidemiology and Public Health - University College London, London, UK 5 - PhD, Graduate Program in Gerontology - Federal University of Sao Carlos, Sao Carlos, Brazil

*Corresponding author:

Department of Gerontology, Federal University of Sao Carlos, Rodovia Washington Luís, km 235, Sao Carlos, Sao Paulo 13565-905, +55 16 3306-6671, e-mail: tiagoalexandre@ufscar.br
\end{abstract}

\title{
Conflicts of Interest:
}

The authors declare no conflicts of interest.

\section{Funding:}

This study was financed in part by the Fundação de Amparo à Pesquisa do Estado de São Paulo (FAPESP [State of Sao Paulo Research Assistance Foundation]; process number: 2017/22818-6). The ELSI-Brazil study is funded by the Brazilian Health Ministry and Ministry of Science and Technology. The Conselho Nacional de Desenvolvimento Cientifico e Tecnológico (CNPq [National Council of Scientific and Technological Development) funds Tiago da Silva Alexandre (process number: 303981/2017-2). 


\begin{abstract}
Background: Type 2 diabetes (DM2) is associated with cognitive impairment. However, most of the evidence has been based on self-reported DM2 and did not consider undiagnosed diabetes as a separate category. We aimed to examine the extent to which undiagnosed diabetes modifies the association between diabetes and cognitive impairment in a representative sample of Brazilian adults aged 50 years and older. Methods: We analyzed baseline data from 1,944 participants of the Brazilian Longitudinal Study of Aging (ELSI-Brazil) conducted in 2015-16. Diabetes was evaluated based on self-reported doctor diagnosis and HbAlc levels. Participants were classified as diabetics (D), undiagnosed diabetes (UDD) or non-diabetics (ND). Cognitive function was assessed by word list learning and verbal fluency tests. Three multiple logistic regression models were used to evaluate the changes in the strength of the associations. Results: Participants with diabetes had a $49 \%$ greater chance of exhibiting impaired memory than non-diabetics (OR=1.49; 95\%CI:1.01-2.20). By combining UDD and ND, the association between diabetes and impaired memory was attenuated by $2.0 \%$, losing its statistical significance (OR=1.46; 95\%CI:0.98-2.17). By combining UDD and $\mathrm{D}$, the association was attenuated by $7.4 \% \quad(\mathrm{OR}=1.38$; 95\%CI:1.01-1.90). No significant association was found between DM2 and impaired verbal fluency. Conclusion: This study found an association between DM2 and impaired memory but not with impaired verbal fluency. When UDD individuals are considered diabetics, this association is attenuated; when UDD individuals are considered as ND, this association is attenuated to the extent that it loses its statistical significance, which affects the clinical interpretation.
\end{abstract}

Key words: aging, cognitive impairment, diabetes mellitus. 


\section{Highlights:}

- DM2 is associated with impaired memory but not with verbal fluency.

- The association between diabetes and impaired memory becomes not significant by combining undiagnosed and non-diabetics in the same category.

- Including undiagnosed diabetics and diabetics in the same category attenuates the association between diabetes and impaired memory. 


\section{INTRODUCTION}

Type 2 diabetes (DM2) is one of the chronic conditions that most compromises the health of older adults and can cause both microvascular and macrovascular problems ${ }^{1,2}$. It is estimated that $8.5 \%$ of the world population has DM2 and the disease currently affects $20 \%$ of the older population ${ }^{3,1}$. Globally, around 193 million people have undiagnosed diabetes and are at risk of DM2 complications ${ }^{4}$.

In its early stages, DM2 may be asymptomatic and, therefore, undiagnosed and untreated $^{2}$. Due to physiopathological complications caused by DM2, researchers have considered diabetes as an important risk factor for cognitive decline later in life , $^{5,6,7}$.

However, a common limitation of studies analyzing the association between DM2 and cognitive decline is the use of only self-report diagnosis for the classification of diabetes. Therefore, undiagnosed individuals are classified as non-diabetic cases, which could lead to an underestimation of this association. Undiagnosed diabetics have high blood glucose levels and are, as a consequence, exposed to the systemic effects of $\mathrm{DM} 2^{8,9}$.

Despite DM2 being associated with cognitive decline in older adults, the impact that undiagnosed diabetes may have on this association is not yet well known. To date, only Downer et al. (2016) investigated this methodological issue. They found that diagnosed diabetics having a $170 \%$ greater chance of severe cognitive impairment ${ }^{10}$. They also showed that not separating undiagnosed diabetics attenuated this association by $6.3 \%$ when they were classified as non-diabetics and $30.4 \%$ when classified as diabetics ${ }^{10}$. 
However, the author's' analyzed global cognitive decline composed of eight domains. In contrast, we separated the analysis of three cognitive domains: memory (one of the most compromised domains during the aging process), language and executive functioning, which are the domains most affected by DM2 after memory ${ }^{11}$. Furthermore, impairment can occur differently in each domain and the identification of the most affected domain by DM2 is essential to the planning of prevention strategies ${ }^{11}$.

Therefore, two hypotheses were tested in the present study: (a) there is an association between diabetes and impaired cognitive function; and (b) not separating undiagnosed diabetics i.e. classifying them as either diabetics or non-diabetics, attenuates the association between diabetes and impairment in cognitive function in Brazilians aged 50 years or older.

\section{METHODS}

\section{Study population}

A cross-sectional analysis was conducted using data from the first wave (2015-16) of the Brazilian Longitudinal Study of Aging (ELSI-Brazil). ELSI-Brazil is representative of the Brazilian population aged 50 years or older living in private households. A complex sampling procedure involved different stages of selection i.e. municipalities, census sectors and homes. An inverse sampling process was adopted, with the estimate of 10,000 participants $(9,412$ participated $)$. The survey was conducted in 70 municipalities in the five major regions of the country. Baseline data collection was performed between 2015 and 2016. Further details on the sampling process can be 


\section{found elsewhere ${ }^{12}$.}

From the 9,412 participants who took part in the baseline of ELSI, the present study used a probabilistic subsample of 4,000 individuals who were selected for blood samples and $59 \%$ of them (2,360 individuals) had glycated hemoglobin (HbA1c) results $^{12}$. Out of the 2,360 individuals who had data on HbAlc, 416 individuals were further excluded for not having information on self-reported diagnosis of diabetes, cognitive assessment or covariates, resulting in a final analytical sample of 1,944 participants. Figure 1 shown the sample selection flowchart.

\section{INSERT FIGURE 1}

\section{Cognitive function assessment: verbal fluency and memory}

Cognitive function was assessed through a validated battery of tests used by the Health and Retirement Study network of aging cohorts from different countries ${ }^{12}$.

The verbal fluency test i.e. animal naming, is a validate test and widely used in epidemiological studies to assess language and executive function ${ }^{13,14}$. More specifically, it measures lexical knowledge, lexical recovery capacity and executive control capacity as demonstrated in previous studies ${ }^{15,16}$. The test consists of asking the participants to name as many as possible animals in one minute. The score is obtained by the total number of animals mentioned. An impaired verbal fluency was defined as a 
cut off of 1.0 standard deviation below the normative mean. This way, those participants who have scored $<8$ points were classified as having a verbal fluency impairment.

The memory variable was assessed through the word list learning test ${ }^{17}$. This test has two parts: immediate and delayed memory. In the first part of the test, the participants heard 10 words and immediately after that they should say the words remembered. The second part of the test occurred after other tests and questions, when the respondents were asked about the 10 words previously heard. A memory score was calculated by adding the number of words correctly mentioned on both parts of the test. The total score could vary from 0 to $20^{17}$. The cut off point for the word list learning test was defined as a value of 1.0 standard deviation below the normative mean. Therefore, a value lower than 5 was classified as a memory impairment.

\section{Diabetes}

Diabetes was evaluated in two ways: self-reported doctor diagnosis and HbAlc serum levels. Participants who reported a diagnosis of diabetes were classified as diabetic (D). Those who did not report having diabetes but had $\mathrm{HbAlc} \geq 6.5 \%$ were classified as undiagnosed diabetic (UDD). Those who reported not having diabetes and had HbA1c $<6.5 \%$ were classified as non-diabetics (ND) ${ }^{18}$.

\section{Covariates}

The socioeconomic characteristics were sex, age, schooling years (illiterate, one to four years, five to eight years and nine or more years), living alone (yes/no), marital status 
(with/without a conjugal life) and income (no income, up to two times the Brazilian monthly minimum wage (BMMW), two to five times the BMMW and five or more times the BMMW). Health behaviors included were physical activity level evaluated using the Brazilian version of the International Physical Activity Questionnaire

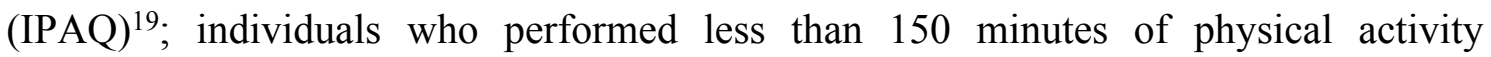
(walking, moderate activity or vigorous activity) per week were classified as insufficiently active ${ }^{20}$. Regarding smoking, participants were classified as non-smokers, former smokers or current smokers. Alcohol intake was measured based on reports of the frequency of consumption (never, once a month or less, two to six times a week or daily). The anthropometric characteristics were body mass index (BMI) classified as undernourished $\left(<18.5 \mathrm{~kg} / \mathrm{m}^{2}\right)$; ideal range $\left(18.5\right.$ to $\left.<25 \mathrm{~kg} / \mathrm{m}^{2}\right)$; overweight $(25$ to $<30$ $\left.\mathrm{kg} / \mathrm{m}^{2}\right)$ and obese $\left(\geq 30 \mathrm{~kg} / \mathrm{m}^{2}\right)^{21}$ and waist circumference $(>102 \mathrm{~cm}$ for men and $>88 \mathrm{~cm}$ for women indicated abdominal obesity $)^{22}$. A waist/hip ratio $\geq 0.90$ for men and $\geq 0.85$ for women indicated cardiovascular risk $^{23}$. The following chronic conditions were included: hypertension (self-reported doctor diagnosis of hypertension and/or the use of anti-hypertensive medications and/or systolic blood pressure higher than $140 \mathrm{mmHg}$ or diastolic blood pressure higher than $90 \mathrm{mmHg}$ ) 24 ; self-reported heart disease (infarction, angina or heart failure), cerebrovascular disease and Alzheimer's disease. The presence of depressive symptoms was evaluated using the eight-item Center for Epidemiological Studies Depression Scale (CES-D), with a score of $\geq 4$ considered indicative positive for such symptoms ${ }^{25}$. We also measured participants' lipid profile: Triglycerides $(\geq 150$ $\mathrm{mg} / \mathrm{dl}$ considered high); total cholesterol ( $\geq 200 \mathrm{mg} / \mathrm{dl}$ considered high); HDL $(<40$ $\mathrm{mg} / \mathrm{dl}$ for men and $<50 \mathrm{mg} / \mathrm{dl}$ for women considered low $)^{23}$. A good glycemic control for the diabetic participants was defined as a $\mathrm{HbAlc}$ level $<7.0 \%$, according to the 
American Diabetes Association (2018) recommendation ${ }^{26}$.

\section{Statistical analysis}

Descriptive statistics were performed for the characterization of the sample. Comparisons among the groups regarding memory and verbal fluency were performed using the Rao-Scott Wald test (comparison of means) and the chi-square test with the Rao-Scott correction (comparison of proportions). The sample characteristics were not adjusted by multiple tests. Three multiple logistic regression models were used to analyze whether undiagnosed diabetes modifies the association between diagnosed diabetes and impaired cognitive function. For the regression models, the covariates were selected based on their relationship with diabetes and/or cognitive impairment and after that, the variables with a $p$-value $<0.20$ in the univariate analysis were selected for the multiple model and variables with a p-value $<0.05$ in the final model were considered significantly associated with the outcome. Based on the existing evidence on the influence of education and age on cognitive function ${ }^{27}$ all models were adjusted for age and education. Model 1 included the three diabetes categories separately: non-diabetic (ND), undiagnosed diabetes (UDD) and diabetes (D). Model 2 combined UDD and ND in the same category and Model 3 combined UDD and D in the same category.

The odds ratios (OR) obtained in Models 1 and 2 were used to calculate the change in the strength of the association between diagnosed diabetes and cognitive impairment according to the different diabetes classification groups adjusted for socioeconomic, health, behavioral and anthropometric characteristics. The equation $\left(\mathrm{OR}_{\text {model }}-\right.$ $\left.\mathrm{OR}_{\text {model } 2}\right) / \mathrm{OR}_{\text {model1 }}$ was used, in which $\mathrm{OR}_{\text {model1 }}$ is the $\mathrm{OR}$ of diabetes from Model 1 and 
$\mathrm{OR}_{\text {model } 2}$ is the OR of diabetes from Model 2. The same formula was applied to Models 1 and 3 to calculate the change in the association when undiagnosed diabetics were in the same category as diabetics. The percentage of change in the association was determined among the three models.

Descriptive statistics, comparison tests and regression models were weighted. The Stata ${ }^{\circledR}$ statistical package (Stata Corp, College Station, TX, USA) version 14.0 was used for the data analyses.

\section{Ethical aspects}

The ELSI-Brazil study received approval from the Human Research Ethics Committee of the René Rachou Research Center of the Oswaldo Cruz Foundation (state of Minas Gerais, Brazil) (certificate number: 886.754). All participants signed a statement of informed consent.

\section{RESULTS}

The prevalence of undiagnosed diabetes was $7.6 \%(95 \% \mathrm{CI}: 6.1$ to 9.5$)$ and the prevalence of diagnosed diabetes was $16.6 \%$ (95\%CI: 14.4 to 19.0$)$. The prevalence of impaired verbal fluency and impaired memory was $14.3 \%(95 \% \mathrm{CI}: 11.3$ to 17.8$)$ and $21.0 \%$ (95\%CI: 17.4 to 25.2$)$, respectively. Tables 1 and 2 displays the characteristics of the overall sample and stratified by the presence/absence of impaired memory and verbal fluency. The individuals excluded due to missing data were older, had lower 
schooling, were less physically active, had less depression and fewer had a conjugal life in comparison to the individuals included in the present study (data not shown).

The participants with impaired verbal fluency were older, had less schooling, lived alone, had no conjugal live and had a lower income than those without impaired verbal fluency $(\mathrm{p}<0.05)$. These participants also were less physically active, had more depressive symptoms, a lower mean of BMI, a lower proportion of obesity (BMI $\geq 30$ $\left.\mathrm{kg} / \mathrm{m}^{2}\right)$, and a lower mean of waist circumference $(\mathrm{p}<0.05)$. No differences in verbal fluency performance were found among the three diabetes groups analyzed (Table 1 and 2).

Individuals with impaired memory were older, had less schooling and had a lower income in comparison to those without impaired memory $(\mathrm{p}<0.05)$. They were less consumers of alcohol, were less active, had a higher prevalence of diabetes and stroke, lower mean of BMI, lower proportion of obesity $\left(\mathrm{BMI} \geq 30 \mathrm{~kg} / \mathrm{m}^{2}\right.$ ), had more depressive symptoms and had a lower prevalence of hypercholesterolemia $(p<0.05)$ (Tables 1 and 2).

When the three diabetes groups were compared, D individuals were older than ND. Compared to ND individuals, both D and UDD individuals had a higher prevalence of hypertension, higher mean BMI, larger waist circumference, higher waist-hip ratio, and higher HbA1c, triglycerides, total and HDL cholesterol serum levels. However, the D group had higher mean triglycerides and total cholesterol values than the UDD $(p<0.05)$ (Supplementary Tables 1 and 2). 
Table 3 displays the odds ratios for the regression models and the change in the strength of the association between diabetes and impaired verbal fluency. In Model 1, no association was found. When including undiagnosed diabetics in the same category as non-diabetics, the chance of impaired verbal fluency was overestimated by $1.0 \%$, with no significant association with (Model 2). When including undiagnosed diabetics in the same category as diabetics, the association between diabetes and impaired verbal fluency was attenuated by $8.0 \%$ but remained non-significant (Model 3). In Model 1, diabetics had a $49 \%$ greater chance of exhibiting impaired memory (OR=1.49 95\%CI: 1.01 to 2.20 ). When including undiagnosed diabetics in the same category as nondiabetics, the association between diabetes and impaired memory was attenuated by $2.0 \%$ and lost its statistical significance ( $\mathrm{OR}=1.46$ 95\% CI: 0.98 to 2.17) (Model 2). When including undiagnosed diabetics in the same category as diabetics, the association was attenuated by $7.4 \%$, maintaining statistical significance $(\mathrm{OR}=1.38$ 95\% $\mathrm{CI}: 1.01$ to 1.90) (Model 3).

\section{DISCUSSION}

The main findings from the first nationally representative aging cohort in Brazil indicate that DM2 increases the chances of memory impairment by $49 \%$ in individuals aged 50 years or older. In addition, there is an attenuation of the association when undiagnosed diabetics are not analyzed separately to the extent of losing its significance when such individuals are classified as non-diabetics. 
There is a robust body of evidence on the association between diabetes and cognitive decline. Our main findings are corroborated by previous studies. Rawlings et al. (2014) using 20 years follow-up data found that diabetes was associated to $19 \%$ higher risk to cognitive decline ${ }^{6}$. A meta-analysis conducted by Zhang et al. (2017) also showed that in diabetics the incidence of Alzheimer's disease was 53\% higher compared to nondiabetics $^{28}$. Another meta-analysis by Palta et al. (2014), demonstrated that diabetics had poorer performance on executive function, processing speed, verbal memory and visual memory compared to non-diabetics ${ }^{29}$.

However, to date, only another study analyzed undiagnosed diabetes as a separate group. Nevertheless, the authors did not test the association with different cognitive domains separately. In a cross-sectional study involving a sample of 1,033 Mexicans aged 60 years or older, Downer et al. (2016) found that diabetics had a $170 \%$ greater chance of exhibiting severe cognitive impairment than non-diabetics. However, this association was attenuated by $6.3 \%$ when undiagnosed diabetics were considered nondiabetics and $30.4 \%$ when the same individuals were considered diabetics ${ }^{10}$.

The findings reported by Downer et al. (2016) are in agreement with our results in terms of memory. In both studies, diabetes was associated with a greater chance of cognitive impairment and including undiagnosed diabetics in the same group as non-diabetics attenuated this association. However, the greater strength of the association and greater percentage of attenuation between diabetes and severe cognitive impairment may be attributed to the fact that Downer et al. (2016) analyzed eight cognitive domains, whereas we analyzed memory and verbal fluency and performed separate analyses for each. Furthermore, the sample used by Downer et al. (2016) was considerably older, 
with a smaller proportion of illiterate individuals and had considerably more women. In addition, the prevalence of diabetic and undiagnosed diabetic individuals within the severe cognitive impairment group was twice as large compared to our study. Their mean $\mathrm{HbA1c}$ value was also higher than in our sample. Finally, our analyses were adjusted for covariates related to cognitive decline that were not used by Downer et al. (2016), enabling better control of the strength of the association found herein ${ }^{10}$.

DM2 as a risk factor for cognitive impairment has been explained by the reduction in cortical perfusion due to vascular microlesions ${ }^{30}$. Frequent hypoglycemia episodes can cause cell death due to a lack of energy. Frequent hyperglycemia episodes predispose an individual to the formation of atheromatous plaque, compromising blood circulation as well as adding the effect of inflammatory cytokines in the cerebral cortex and causing abnormalities in the homeostasis of the autonomic nervous system ${ }^{31,32,33,34}$. There is also evidence that chronic hyperglycemia is associated with the significant loss of cortical neurons and a reduction in cholinergic transmission, which is thought to result in impaired memory ${ }^{35}$. Gold et al. (2007) found that diabetic individuals have a smaller volume of the hippocampus and that there is an inverse relation between glycemic control and hippocampus size. As the hippocampus is more susceptible to harm due to severe hypoglycemia and hypoxia, it is understandable that this structure is the first affected by DM2. With the progression of the disease, other areas of the brain are also affected, with the occurrence of global atrophy and white matter disease, contributing to cognitive deficiencies and impaired recent memory ${ }^{36}$. 
In the present study, no association was found between diabetes and impaired verbal fluency in any of the models tested. In contrast, Palta and collaborators (2018) using data from a longitudinal study involving 3,069 individuals aged 72 to 96 years found no significant difference on languages tests (including verbal fluency test) between diabetics and non-diabetics at the onset of the study. However, diabetic participants had a worse performance on the phonemic verbal fluency test over the six years of followup. Thus, the lack of a difference between diabetics and non-diabetics regarding verbal fluency in the present investigation could be attributed to the cross-sectional design of the study. On the other hand, Palta et al. (2018) only used self-reported classification of diabetes and did not consider undiagnosed diabetics as a different category ${ }^{11}$. According to Parente et al. (1999), one's performance in terms of language and executive functioning depends on the capacity and integrity of memory ${ }^{37}$. Therefore, a possible explanation for the non-association between diabetes and impaired verbal fluency may be temporal, that is, impaired memory may occur prior to impairments in language and executive functioning, which lends support to the findings described by Palta et al. $(2018)^{10}$.

The observed loss of statistical significance of the association between DM2 and memory impairment when undiagnosed diabetics are included in the non-diabetic category (model 2) as well as the underestimation of this association when undiagnosed diabetic individuals are included in the diagnosed diabetes group (model 3) could be explained by the fact that undiagnosed individuals have less severe diabetes compared to those with diagnosed diabetes. In addition, Zilliox et al. (2016) found that time living with diabetes has a strong impact on the type and severity of cognitive decline ${ }^{38}$. 
Similarly, Rawlings et al. (2014) showed that there is a stronger association between cognitive deficit and diabetes of long duration ${ }^{6}$. Therefore, undiagnosed diabetic individuals have a shorter period living with the condition and being exposed to hyperglycemia. This way, they have potentially fewer negative effects on their cognitive function, especially memory, compared to diagnosed diabetics. Moreover, there is some evidence showing that the presence of other conditions and their related complications is higher in diagnosed diabetics compared to non-diabetics ${ }^{39}$ which would support our findings.

To the best of our knowledge, this is the first nationally representative study to investigate the association between undiagnosed DM and cognitive function in Brazilian older adults. The strengths of this study include its large sample size, which ensured the representativeness of Brazilian men and women aged 50 years or older, and the use of different regression models, which enabled identifying that the inclusion of undiagnosed diabetes in the non-diabetic group may not be the most adequate way to analyze this condition in epidemiological studies. This study also has limitations that should be acknowledged. No information was collected on the duration of the disease. The fact that the excluded individuals were older, had less schooling, had a lower frequency of a conjugal life and were less physically active may have led to some degree of bias in the associations found. The fact that we only had a single HbAlc measurement to classify the participants in diabetics and undiagnosed diabetics could have potentially influenced in their classification. However, despite these limitations, it was possible to find an association between diabetes and impaired memory and prove the initial hypothesis of 
the study. A further limitation relates to its cross-sectional design, which does not allow establishing causality.

Since memory is an earlier indicator of cognitive impairment, the association between diabetes and its impairment is clinically relevant. Clinicians should diagnose as earlier as possible diabetes as well as its negative impact on cognitive function.

\section{CONCLUSION}

Older Brazilian adults with diabetes are more likely to have impaired memory. In addition, by not separating undiagnosed diabetes there is an attenuation of this association to the extent that it loses its significance when such individuals are analyzed as non-diabetics. This association is also attenuated when undiagnosed diabetics are considered diabetics. No association was found between diabetes and impaired verbal fluency. This may be explained by the deterioration of memory prior to the decline in language and executive functioning, which is an issue that needs to be examined longitudinally.

\section{ACKNOWLEDGMENTS}

This study was finance in part by the Fundação de Amparo à Pesquisa do Estado de São Paulo (FAPESP [State of Sao Paulo Research Assistance Foundation]; process number: 2017/22818-6). The ELSI-Brazil study is funded by the Brazilian Health Ministry and Ministry of Science and Technology. The Conselho Nacional de Desenvolvimento Científico e Tecnológico (CNPq [National Council of Scientific and 
Technological Development) funds Tiago da Silva Alexandre (process number: 303981/2017-2).

\section{DISCLOSURE}

The authors declare that they have no conflict of interest. 


\section{REFERENCES}

1. World Health Organization. Global Report on Diabetes. 2016. https://apps.who.int/iris/bitstream/handle/10665/204871/9789241565257_eng.pdf;js essionid=B952B3BF1CDA52CF918F8C7003A42BFD? sequence=1

2. Sociedade Brasileira de Diabetes. Diretrizes SBD. Rio de Janeiro, 2015-2016. http://www.diabetes.org.br/sbdonline/images/docs/DIRETRIZES-SBD-20152016.pdf

3. Sinclair A, Morley JE, Rodriguez-Mañas L, Paolisso G, Bayer T, Zeyfang A, et al. Diabetes mellitus in older people: Position statement on behalf of the International Association of Gerontology and Geriatrics (IAGG), the European Diabetes Working Party for Older People (EDWPOP), and the International Task Force of Experts in Diabetes. J Am Med Dir Assoc. 2012; 13:497-502. doi:10.1016/j.jamda.2012.04.012.

4. International Diabetes Federation. IDF Diabetes Atlas, 7th edn. Brussels, Belgium: International Diabetes Federation, 2015.

5. Xu W, Qiu C, Gatz M, Pedersen NL, Johansson B, Fratiglioni L. Mid-and latelife diabetes in relation to the risk of dementia: a population-based twin study. Diabetes. 2009; 58:71-77. doi:10.2337/db08-0586.

6. Rawlings AM, Sharrett AR, Schneider AL, Coresh J, Albert M, Couper D, et al. Diabetes in midlife and cognitive change over 20 years: a cohort study. Ann Intern Med. 2014; 161(11):785-93. doi:10.7326/M14-0737.

7. Ahtiluoto S, Polvikoski T, Peltonen M, Solomon A, Tuomilehto J, Winblad B, et al. Diabetes, Alzheimer disease, and vascular dementia: a population-based 
neuropathologic study. Neurology. 2010; 75(13):1195-1202. doi:10.1212/WNL.0b013e3181f4d7f8.

8. Diaz-Apodaca BA, Ebrahim S, Mccormack V, de Cosio FG, Ruiz-Holguin R. Prevalence of type 2 diabetes and impaired fasting glucose: cross-sectional study of multiethnic adult population at the United States-Mexico border. Rev Panam Salud Pública. 2010; 28(3):174-181. doi:10.1590/s1020-49892010000900007.

9. Blaum CS, Ofstedal MB, Langa KM, Wray LA. Functional status and health outcomes in older Americans with diabetes mellitus. J Am Geriatric Soc. 2003; 51(6):745-753. doi:10.1046/j.1365-2389.2003.51256.x.

10. Downer B, Kumar A, Mehta H, Al Snih S, Wong R. The Effect of Undiagnosed Diabetes on the Association Between Self-Reported Diabetes and Cognitive Impairment Among Older Mexican Adults. American Journal of Alzheimer's Disease \& Other Dementias. 2016; 31(7):564-569. doi:10.1177/1533317516653824.

11. Palta P, Carlson M, Crum RM, Colantuoni E, Sharrett AR, Yasar S, et al. Diabetes and Cognitive Decline in Older Adults: The Ginkgo Evaluation of Memory Study. J Gerontol A Biol Sci Med Sci. 2018; 73(1):123-130. doi:10.1093/gerona/glx076.

12. Lima-Costa MF, de Andrade FB, de Souza PRB Jr, Neri AL, Duarte YAO, CastroCosta E, et al. The Brazilian Longitudinal Study of Aging (ELSI-Brazil): Objectives and Design, American Journal of Epidemiology. 2018; 187(7):1345-1353. doi:10.1093/aje/kwx387.

13. Passos VMA, Giatti L, Barreto SM, Figueiredo RC, Caramelli P, Benseñor I, et al. Verbal fluency tests reliability in a Brazilian multicentric study, ELSA-Brasil. Arq Neuropsiquiatr. 2011; 69(5):814-816. doi.org/10.1590/S0004-282X2011000600017. 
14. Schmidt CSM, Schumacher LV, Romer P, Leonhart R, Beume L, Martin M, Kaller CP. Are semantic and phonological fluency based on the same or distinct sets of cognitive processes? Insights from factor analyses in healthy adults and stroke patients. Neuropsychologia. 2017; 99:148-155. doi:10.1016/j.neuropsychologia.2017.02.019.

15. Federmeier KD, Kutas M, Schul R. Age-related and individual differences in the use of prediction during language comprehension. Brain Lang. 2020; 115:149-161. doi:10.1016/j.band1.2010.07.006.

16. Fitzpatrick S, Gilbert SJ, Serpell LE. Systematic review: are overweight and obese individuals impaired on behavioural tasks of executive functioning? Neuropsychol. Rev. 2013; 23:138-156. doi:10.1007/s11065-013-9224-7.

17. Ofstedal M, Fisher G, Herzog A. Documentation of Cognitive Functioning Measures in the Health and Retirement Study, 2005. http://hrsonline.isr.umich.edu/docs/userg/dr-006.pdf (last accessed September 2008).

18. American Diabetes Association. Standards of Medical Care in Diabetes. Diabetes Care. 2013; 36(1):11-66. doi:10.2337/dc13-S011.

19. Guedes DP, Lopes CC, Guedes JERP. Reprodutibilidade e validade do Questionário Internacional de Atividade Física em adolescentes. Rev Bras Med Esp. 2005; 11(2):151-157. doi:10.1590/s1517-86922005000200011.

20. Garber CE, Blissmer B, Deschenes MR, Franklin BA, Lamonte MJ, Lee IM, et al. Quantity and Quality of Exercise for Developing and Maintaining Cardiorespiratory, Musculoskeletal, and Neuromotor Fitness in Apparently Healthy Adults: Guidance 
for Prescribing Exercise. In: Official Journal of the American College of Sports Medicine. 2011; p 1334-1359. doi:10.1249/MSS.0b013e318213fefb.

21. World Health Organization. Obesity: Preventing and Managing the Global Epidemic. Switzerland: WHO; 2000. WHO Technical Report Series 894. doi: $10.1017 / \mathrm{s} 0021932003245508$

22. National Institutes of Health. Clinical guidelines on the identification, evaluation, and treatment of overweight and obesity in adults: the evidence report [published correction appears in Obesity Research, v. 6, p. 464, 1998]. Obesity Research. 1998; 6(2):51-209.

23. National Institutes of Health. Third Report of the National Cholesterol Education Program (NCEP) Expert Panel on Detection, evaluation, and treatment of high blood cholesterol in adults (Adult Treatment Panel III). 2002; 106(25):3143-3421. https://www.nhlbi.nih.gov/files/docs/resources/heart/atp-3-cholesterol-fullreport.pdf

24. World Health Organization. A global brief on hypertension: silent killer, global public health crisis: World Health Day 2013. World Health Organization. https://apps.who.int/iris/handle/10665/79059

25. Gallagher D, Kiss A, Lanctot K, Herrmann N. Depressive symptoms and cognitive decline: a longitudinal analysis of potentially modifiable risk factors in community dwelling older adults. J Affect Disord Elsevier. 2016; 190:235-240. doi:10.1016/j.jad.2015.09.046.

26. American Diabetes Association. Glycemic targets: standards of medical care in diabetes - 2018. Diabetes Care. 2018; 41(Suppl.1):S55-64. doi 10.2337/dc18-S006. 
27. Brucki SMD, Rocha MSG. Category fluency test: effects of age, gender and education on total scores, clustering and switching in Brazilian Portuguese-speaking subjects. Braz J Med Biol Res. 2004; 37(12): 1771-1777. doi.org/10.1590/S0100879X2004001200002.

28. Zhang J, Chen C, Hua S, Liao H, Wang M, Xiong Y, Cao F. An updated metaanalysis of cohort studies: Diabetes and risk of Alzheimer's disease. Diabetes Research and Clinical Practice. 2017; 124:41-47. doi:10.1016/j.diabres.2016.10.024.

29. Palta P, Schneider AL, Biessels GJ, Touradji P, Hill-Briggs F. Magnitude of cognitive dysfunction in adults with type 2 diabetes: a meta-analysis of six cognitive domains and the most frequently reported neuropsychological tests within domains. J Int Neuropsychol Soc. 2014; 20(3):278-91. doi:10.1017/S1355617713001483.

30. Manschot SM, Biessels GJ, de Valk H, Algra A, Rutten GE, Van Der Grond J, et al. Metabolic and vascular determinants of impaired cognitive performance and abnormalities on brain magnetic resonance imaging in patients with type 2 diabetes. Diabetologia. 2007; 50(11):2388-2397. doi:10.1007/s00125-007-0792-z.

31. Awad N, Gagnon M, Messier C. The relationship between impaired glucose tolerance, type 2 diabetes, and cognitive function. Journal of Clinical and Experimental Neuropsychology. 2004; 26(8):1044-1080. doi:10.1080/13803390490514875.

32. Haan MN. Therapy insight: type 2 diabetes mellitus and the risk of late-onset Alzheimer's disease. Nat Clin Pract Neurol. 2006; 2:159-166. doi:10.1038/ncpneuro0124. 
33. Fernandez-Real JM, Pickup JC. Innate immunity, insulin resistance and type 2 diabetes. Trends Endocrinol Metab. 2008; 19(1):10-16. doi:10.1016/j.tem.2007.10.004.

34. Strachan MWRD. Lawrence Lecture 2010. The brain as a target organ in type 2 diabetes: exploring the links with cognitive impairment and dementia. Diabet Med. 2011; 28(2):141-147. doi:10.1111/j.1464-5491.2010.03199.x.

35. Kumari M, Brunner E, Fuhrer R. Minireview: Mechanisms by Which the Metabolic Syndrome and Diabetes Impair Memory. The Journals of Gerontology: Series A. 2000; 55(5):B228-B232. doi:10.1093/gerona/55.5.B228.

36. Gold SM, Dziobek I, Sweat V, Tirsi A, Rogers K, Bruehl H, et al. Hippocampal damage and memory impairments as possible early brain complications of type 2 diabetes. Diabetologia. 2007; 50(4):711-719. doi:10.1007/s00125-007-0602-7.

37. Parente MAMP, Saboskinski AP, Ferreira E, Nespoulous J-L. Memória e compreensão da linguagem no envelhecimento. Est. Interdiscipl. Envelhec. 1999; 60(1):57-76.

38. Zilliox LA, Chadrasekaran K, Kwan JY, Russell JW. Diabetes and Cognitive Impairment. Current Diabetes Reports. 2016; 16(9):1-11.doi:10.1007/s11892-0160775-X.

39. Kumar A, Wong R, Ottenbacher KJ, Al Snih S. Prediabetes, undiagnosed diabetes, and diabetes among Mexican adults: findings from the Mexican Health and Aging Study. Annals of Epidemiology. 2016; 26(3):163-170. doi:10.1016/j.annepidem.2015.12.006. 


\section{Figure Legends}

Figure 1 - Sample selection flowchart. 
Table 1 - Socioeconomic and behavioral characteristics of 1,944 participants of the ELSI-Brazil study according verbal fluency and memory status (2015-16)

\begin{tabular}{|c|c|c|c|c|c|}
\hline Socioeconomic characteristics & $\begin{array}{c}\text { Total } \\
(\mathrm{n}=1,944)\end{array}$ & $\begin{array}{l}\text { Normal Verbal Fluency } \\
\qquad(\mathrm{n}=1,640)\end{array}$ & $\begin{array}{l}\text { Impaired Verbal Fluency } \\
\qquad(\mathrm{n}=304)\end{array}$ & $\begin{array}{l}\text { Normal Memory } \\
\quad(n=1,485)\end{array}$ & $\begin{array}{c}\text { Impaired Memory } \\
\qquad(\mathrm{n}=459)\end{array}$ \\
\hline $\begin{array}{l}\text { Age, years }(\mathrm{SD}) \\
50-59 \text { years, }(\%) \\
60-69 \text { years, }(\%) \\
70-79 \text { years, }(\%) \\
80-89 \text { years, }(\%) \\
90 \text { years or more, }(\%) \\
\text { Sex (female), }(\%)\end{array}$ & $\begin{array}{c}62.1 \pm 9.2 \\
48.4 \\
30.7 \\
15.3 \\
4.9 \\
0.7 \\
53.6\end{array}$ & $\begin{array}{c}61.6 \pm 8.7^{\mathrm{a}} \\
49.5 \\
31.9 \\
14.3 \\
3.8^{\mathrm{a}} \\
0.5 \\
52.6\end{array}$ & $\begin{array}{l}65.1 \pm 11.7^{\mathrm{a}} \\
41.7 \\
23.7 \\
21.1 \\
11.5^{\mathrm{a}} \\
2.0 \\
59.2\end{array}$ & $\begin{array}{l}60.6 \pm 8.0^{\mathrm{b}} \\
55.1^{\mathrm{b}} \\
29.9^{\mathrm{b}} \\
12.0^{\mathrm{b}} \\
2.8^{\mathrm{b}} \\
0.2 \\
54.3\end{array}$ & $\begin{array}{l}68.1 \pm 11.2^{\mathrm{b}} \\
23.4^{\mathrm{b}} \\
33.7^{\mathrm{b}} \\
27.8^{\mathrm{b}} \\
12.8^{\mathrm{b}} \\
2.3 \\
50.8\end{array}$ \\
\hline $\begin{array}{l}\text { Schooling, (\%) } \\
\text { Illiterate } \\
1-4 \text { years } \\
\text { 5-8 years } \\
9 \text { years or more } \\
\text { Lives alone (yes), (\%) } \\
\text { Marital status (without conjugal life), (\%) }\end{array}$ & $\begin{array}{c}11.4 \\
40.1 \\
18.8 \\
29.7 \\
7.8 \\
33.8\end{array}$ & $\begin{array}{c}8.9^{\mathrm{a}} \\
38.8 \\
19.6 \\
32.7^{\mathrm{a}} \\
6.9^{\mathrm{a}} \\
32.2^{\mathrm{a}}\end{array}$ & $\begin{array}{l}27.0^{\mathrm{a}} \\
48.0 \\
13.8 \\
11.2^{\mathrm{a}} \\
13.5^{\mathrm{a}} \\
43.7^{\mathrm{a}}\end{array}$ & $\begin{array}{c}6.9^{\mathrm{b}} \\
37.1^{\mathrm{b}} \\
20.8^{\mathrm{b}} \\
35.2^{\mathrm{b}} \\
7.3^{3} \\
31.7\end{array}$ & $\begin{array}{l}28.2^{\mathrm{b}} \\
51.7^{\mathrm{b}} \\
11.3^{\mathrm{b}} \\
8.8^{\mathrm{b}} \\
10.0 \\
41.8\end{array}$ \\
\hline $\begin{array}{l}\text { Income, }(\%) \\
\text { No income } \\
<2 \times \text { BMMW } \\
2-5 \times \text { BMMW } \\
\geq 5 \times \text { BMMW } \\
\text { Did not answer }\end{array}$ & $\begin{array}{c}1.3 \\
29.5 \\
44.7 \\
20.8 \\
3.7\end{array}$ & $\begin{array}{c}1.5 \\
26.2^{\mathrm{a}} \\
45.6 \\
23.2^{\mathrm{a}} \\
3.5\end{array}$ & $\begin{array}{c}0.4 \\
49.2^{\mathrm{a}} \\
39.0 \\
6.6^{\mathrm{a}} \\
4.8\end{array}$ & $\begin{array}{c}1.3 \\
25.8^{\mathrm{b}} \\
44.6 \\
24.5^{\mathrm{b}} \\
3.8\end{array}$ & $\begin{array}{c}1.2 \\
43.5^{\mathrm{b}} \\
44.8 \\
6.8^{\mathrm{b}} \\
3.7\end{array}$ \\
\hline Behavioral characteristics & & & & & \\
\hline $\begin{array}{l}\text { Alcohol intake, }(\%) \\
\text { Never } \\
\text { > once per month } \\
\text { 2-6 times a week } \\
\text { Daily } \\
\text { Did not answer }\end{array}$ & $\begin{array}{c}71.2 \\
8.1 \\
13.7 \\
3.0 \\
4.0\end{array}$ & $\begin{array}{l}69.9 \\
8.8 \\
14.6 \\
2.6 \\
4.1\end{array}$ & $\begin{array}{l}78.9 \\
3.7 \\
8.3 \\
5.6 \\
3.5\end{array}$ & $\begin{array}{l}68.7^{\mathrm{b}} \\
9.2^{\mathrm{b}} \\
15.1 \\
2.7 \\
4.3\end{array}$ & $\begin{array}{l}80.8^{\mathrm{b}} \\
3.8^{\mathrm{b}} \\
8.4 \\
4.3 \\
2.7\end{array}$ \\
\hline $\begin{array}{c}\text { Tobacco use, }(\%) \\
\text { Non-smoker } \\
\text { Ex-smoker } \\
\text { Smoker }\end{array}$ & $\begin{array}{l}44.5 \\
39.8 \\
15.7\end{array}$ & $\begin{array}{l}44.7 \\
38.9 \\
16.4\end{array}$ & $\begin{array}{l}43.7 \\
45.1 \\
11.2\end{array}$ & $\begin{array}{l}45.1 \\
38.0 \\
16.9\end{array}$ & $\begin{array}{l}42.7 \\
46.4 \\
10.9\end{array}$ \\
\hline $\begin{array}{l}\text { Physical activity level, (\%) } \\
\text { Active } \\
\text { Insufficiently active } \\
\text { Did not answer }\end{array}$ & $\begin{array}{c}64.8 \\
27.5 \\
7.7\end{array}$ & $\begin{array}{c}68.5^{\mathrm{a}} \\
24.5^{\mathrm{a}} \\
7.0\end{array}$ & $\begin{array}{c}42.6^{\mathrm{a}} \\
45.8^{\mathrm{a}} \\
11.6\end{array}$ & $\begin{array}{c}69.1^{\mathrm{b}} \\
23.7^{\mathrm{b}} \\
7.2^{\mathrm{b}}\end{array}$ & $\begin{array}{c}48.7^{\mathrm{b}} \\
42.0^{\mathrm{b}} \\
9.3^{\mathrm{b}}\end{array}$ \\
\hline
\end{tabular}

BMMW - Brazilian monthly minimum wage; Means, standard deviation (SD) and proportions calculated considering sample weight. Normal verbal fluency: $\geq 8$ points in verbal fluency test. Normal memory: $\geq 5$ points in word list learning test. ${ }^{a}$ Significantly different from normal verbal fluency; ${ }^{b}$ Significantly different from normal memory; $\mathrm{p}<0.05$. 
Table 2 - Clinical, anthropometric and biochemical characteristics of 1,944 participants of ELSI-Brazil study according verbal fluency and memory status

$(2015-16)$

\begin{tabular}{|c|c|c|c|c|c|}
\hline Health conditions & $\begin{array}{c}\text { Total } \\
(n=1,944)\end{array}$ & $\begin{array}{c}\text { Normal verbal fluency } \\
\qquad(\mathrm{n}=1,640)\end{array}$ & $\begin{array}{l}\text { Impaired Verbal Fluency } \\
(\mathrm{n}=304)\end{array}$ & $\begin{array}{l}\text { Normal Memory } \\
\quad(n=1,485)\end{array}$ & $\begin{array}{c}\text { Impaired Memory } \\
(\mathrm{n}=459)\end{array}$ \\
\hline $\begin{array}{l}\text { Diabetes Mellitus, }(\%) \\
\text { Non-diabetics, }(\%) \\
\text { Undiagnosed diabetics, }(\%) \\
\text { Self-reported diabetics, }(\%) \\
\text { Verbal Fluency (impaired), }(\%) \\
\text { Memory (impaired), }(\%) \\
\text { Systemic arterial hypertension (yes), }(\%) \\
\text { Cardiovascular disease (yes), }(\%) \\
\text { Stroke (yes), }(\%) \\
\text { Alzheimer disease (yes), }(\%) \\
\text { Depressive symptoms, }(\%) \\
\text { No }<4 \text { points } \\
\text { Yes } \geq 4 \text { points } \\
\text { Did not answer }\end{array}$ & $\begin{array}{c}75.8 \\
7.6 \\
16.6 \\
14.3 \\
21.0 \\
65.7 \\
14.3 \\
5.6 \\
0.6 \\
\\
46.8 \\
46.8 \\
6.4\end{array}$ & $\begin{array}{l}65.4 \\
14.4 \\
4.7 \\
0.2 \\
49.1^{\mathrm{a}} \\
45.3^{\mathrm{a}} \\
5.6\end{array}$ & $\begin{array}{l}67.8 \\
13.8 \\
10.4 \\
2.6 \\
\\
33.0^{\mathrm{a}} \\
56.1^{\mathrm{a}} \\
10.9\end{array}$ & $\begin{array}{c}64.9 \\
14.5 \\
4.7^{\mathrm{b}} \\
0.2^{2} \\
49.8^{\mathrm{b}} \\
45.0^{\mathrm{b}} \\
5.2^{\mathrm{b}}\end{array}$ & $\begin{array}{l}68.8 \\
13.8 \\
8.8^{\mathrm{b}} \\
1.9 \\
35.8^{\mathrm{b}} \\
53.4^{\mathrm{b}} \\
10.8^{\mathrm{b}}\end{array}$ \\
\hline Anthropometric characteristics & & & & & \\
\hline $\begin{array}{l}\text { Body mass index, (SD) } \\
\text { Ideal } 18.5 \text { to }<25 \mathrm{~kg} / \mathrm{m}^{2},(\%) \\
\text { Undernourished }<18.5 \mathrm{~kg} / \mathrm{m}^{2},(\%) \\
\quad \text { Overweight } 25 \text { to }<30 \mathrm{~kg} / \mathrm{m}^{2},(\%) \\
\quad \text { Obesity } \geq 30 \mathrm{~kg} / \mathrm{m}^{2},(\%) \\
\text { Waist circumference, (SD) } \\
\quad>102 \mathrm{~cm} \text { men }>88 \mathrm{~cm} \text { women } \\
\text { Waist/hip ratio, (SD) } \\
\quad \geq 0.90 \text { men } \geq 0.85 \text { women } \\
\end{array}$ & $\begin{array}{c}27.9 \pm 5.2 \\
27.6 \\
2.4 \\
38.8 \\
31.2 \\
93.6 \pm 12.7 \\
42.8 \\
0.9 \pm 0.1 \\
80.9 \\
\end{array}$ & $\begin{array}{c}28.1 \pm 5.2^{\mathrm{a}} \\
27.0 \\
2.5 \\
37.4 \\
33.1^{\mathrm{a}} \\
93.9 \pm 12.6^{\mathrm{a}} \\
44.2 \\
0.9 \pm 0.1 \\
80.8 \\
\end{array}$ & $\begin{array}{c}27.0 \pm 5.0^{\mathrm{a}} \\
30.7 \\
1.8 \\
47.7 \\
19.8^{\mathrm{a}} \\
92.0 \pm 12.6^{\mathrm{a}} \\
34.6 \\
0.9 \pm 0.1 \\
81.7 \\
\end{array}$ & $\begin{array}{c}28.2 \pm 5.2^{\mathrm{b}} \\
26.9 \\
2.3 \\
37.4 \\
33.4^{\mathrm{b}} \\
93.7 \pm 12.6 \\
43.2 \\
0.9 \pm 0.1 \\
80.6 \\
\end{array}$ & $\begin{array}{c}27.1 \pm 5.1^{\mathrm{b}} \\
30.2 \\
2.9 \\
44.4 \\
22.5^{\mathrm{b}} \\
93.3 \pm 12.9 \\
41.5 \\
0.9 \pm 0.1 \\
82.1 \\
\end{array}$ \\
\hline Biochemical characteristics & & & & & \\
\hline $\begin{array}{l}\text { Glycated hemoglobin, (SD) } \\
\geq 7.0,(\%) \\
\text { Triglycerides, (SD) } \\
\geq 150 \mathrm{mg} / \mathrm{dl},(\%) \\
\text { Total Cholesterol, (SD) } \\
\quad \geq 200 \mathrm{mg} / \mathrm{dl},(\%) \\
\text { HDL, (SD) } \\
\quad<40 \mathrm{mg} / \mathrm{dl} \mathrm{men}<50 \mathrm{mg} / \mathrm{dl} \text { women, }(\%)\end{array}$ & $\begin{array}{c}6.1 \pm 1.3 \\
12.4 \\
181.2 \pm 113.4 \\
50.9 \\
191.2 \pm 41.1 \\
40.5 \\
46.9 \pm 14.4 \\
50.5 \\
\end{array}$ & $\begin{array}{c}6.1 \pm 1.3 \\
12.4 \\
181.8 \pm 113.7 \\
51.0 \\
190.6 \pm 40.5 \\
40.2 \\
46.7 \pm 14.1 \\
50.7 \\
\end{array}$ & $\begin{array}{c}6.1 \pm 1.5 \\
12.7 \\
177.6 \pm 110.8 \\
50.3 \\
195.1 \pm 44.2 \\
42.3 \\
48.1 \pm 16.6 \\
49.3\end{array}$ & $\begin{array}{c}6.1 \pm 1.3 \\
12.3 \\
183.1 \pm 114.9 \\
50.6 \\
192.7 \pm 39.6 \\
42.7^{\mathrm{b}} \\
46.9 \pm 13.9 \\
51.1 \\
\end{array}$ & $\begin{array}{c}6.1 \pm 1.5 \\
12.7 \\
173.8 \pm 104.7 \\
51.9 \\
185.9 \pm 46.2 \\
32.3^{b} \\
47.2 \pm 16.7 \\
48.4 \\
\end{array}$ \\
\hline
\end{tabular}

Means, standard deviation (SD) and proportions calculated considering sample weight. Normal verbal fluency: $\geq 8$ points in verbal fluency test. Normal memory: $\geq 5$ points in word list learning test. ${ }^{\mathrm{a}}$ Significantly different from normal verbal fluency; ${ }^{\mathrm{b}}$ Significantly different from normal memory; $\mathrm{p}<0.05$. 
Table 3 - Final multiple logistic regression models for impairment in verbal fluency and memory and changes in OR according to different diabetes classification groups in 1,944 participants of ELSI-Brazil study (2015-16)

\begin{tabular}{|c|c|c|c|c|}
\hline & $\begin{array}{c}\text { Impaired Verbal Fluency } \\
\text { OR }(95 \% \mathrm{CI}) \\
(\mathrm{n}=1,944)\end{array}$ & $\begin{array}{c}\text { Percentage change } \\
\text { compared to Model } 1(\%)\end{array}$ & $\begin{array}{c}\text { Impaired Memory } \\
\text { OR }(95 \% \mathrm{CI}) \\
(\mathrm{n}=1,944)\end{array}$ & $\begin{array}{c}\text { Percentage change } \\
\text { compared to Model } 1(\%)\end{array}$ \\
\hline \multicolumn{5}{|l|}{ Model 1} \\
\hline ND & 1.00 & - & 1.00 & - \\
\hline UDD & $0.81(0.45-1.45)$ & - & $1.17(0.68-2.02)$ & - \\
\hline $\mathrm{D}$ & $1.00(0.63-1.52)$ & - & $1.49(1.01-2.20)$ & - \\
\hline \multicolumn{5}{|l|}{ Model 2} \\
\hline ND + UDD & 1.00 & - & 1.00 & - \\
\hline $\mathrm{D}$ & $1.01(0.66-1.54)$ & +1.0 & $1.46(0.98-2.17)$ & -2.0 \\
\hline \multicolumn{5}{|l|}{ Model 3} \\
\hline ND & 1.00 & -1 & 1.00 & - \\
\hline UDD + D & $0.92(0.62-1.37)$ & -8.0 & $1.38(1.01-1.90)$ & -7.4 \\
\hline
\end{tabular}


Initial sample $\mathrm{N}=9,412$

Figure 1 - Sample selection flowchart. $180 \times 149 \mathrm{~mm}(300 \times 300$ DPI)

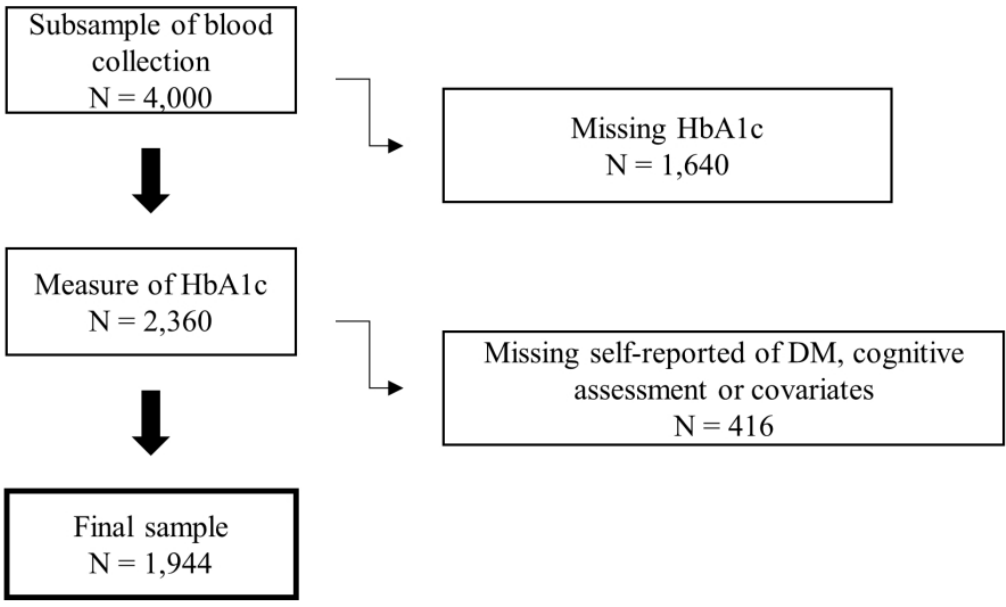


Supplementary Table 1 - Socioeconomic and behavioral characteristics of 1,944 participants of the ELSI-Brazil study according diabetes status (2015-16)

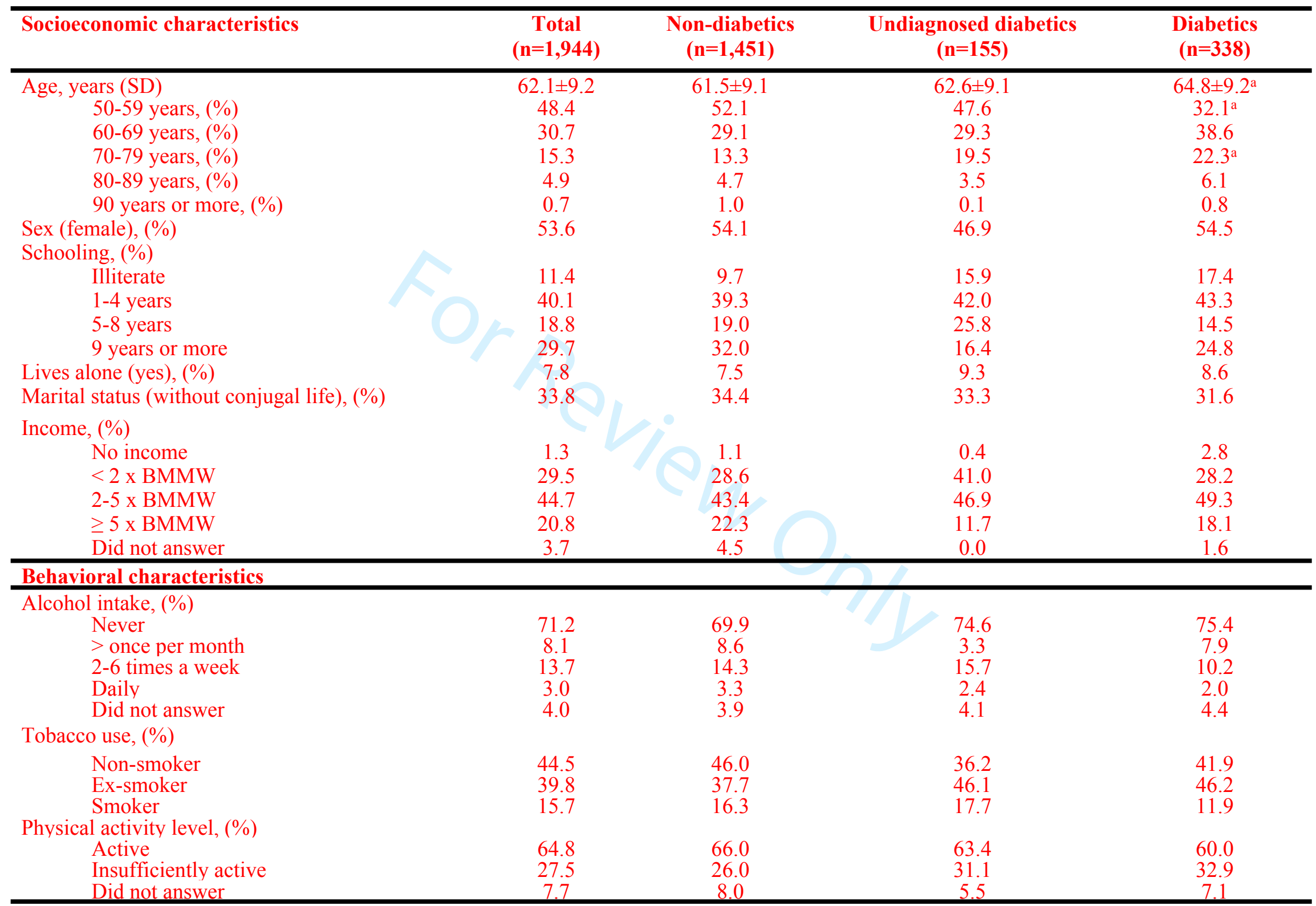

BMMW - Brazilian monthly minimum wage; Means, standard deviation (SD) and proportions calculated considering sample weight. ${ }^{a}$ Significantly different from non-diabetics. ${ }^{b}$ Significantly different from undiagnosed diabetics 
Supplementary Table 2 - Clinical, anthropometric and biochemical characteristics of 1,944 participants of ELSI-Brazil study according verbal fluency and memory status (2015-16)

\begin{tabular}{|c|c|c|c|c|}
\hline Health conditions & $\begin{array}{c}\text { Total } \\
(\mathrm{n}=1,944)\end{array}$ & $\begin{array}{l}\text { Non-diabetics } \\
\quad(n=1,451)\end{array}$ & $\begin{array}{l}\text { Undiagnosed diabetics } \\
\qquad(\mathrm{n}=155)\end{array}$ & $\begin{array}{l}\text { Diabetics } \\
(\mathrm{n}=338)\end{array}$ \\
\hline Verbal Fluency (impaired), (\%) & 14.3 & 14.2 & 13.0 & 15.0 \\
\hline Memory (impaired), (\%) & 21.0 & 18.8 & 24.6 & $29.4^{\mathrm{a}}$ \\
\hline Systemic arterial hypertension (yes), (\%) & 65.7 & 62.5 & $77.9^{\mathrm{a}}$ & $75.1^{\mathrm{a}}$ \\
\hline $\begin{array}{l}\text { Cardiovascular disease (yes), }(\%) \\
\text { Stroke (yes), }(\%)\end{array}$ & $\begin{array}{l}14.3 \\
5.6\end{array}$ & $\begin{array}{l}13.5 \\
5.4\end{array}$ & $\begin{array}{l}14.3 \\
8.1\end{array}$ & $\begin{array}{l}18.3 \\
5.1\end{array}$ \\
\hline $\begin{array}{l}\text { Alzheimer disease (yes), (\%) } \\
\text { Depressive symptoms, }(\%)\end{array}$ & 0.6 & 0.3 & 0.0 & 1.8 \\
\hline $\begin{array}{l}\text { No }<4 \text { points } \\
\text { Yes } \geq 4 \text { points } \\
\text { Did not answer }\end{array}$ & $\begin{array}{r}46.8 \\
46.8 \\
6.4\end{array}$ & $\begin{array}{l}47.9 \\
46.5 \\
5.6\end{array}$ & $\begin{array}{l}53.0 \\
37.0 \\
10.0\end{array}$ & $\begin{array}{l}39.1 \\
52.4 \\
8.5\end{array}$ \\
\hline \multicolumn{5}{|l|}{ Anthropometric characteristics } \\
\hline $\begin{array}{l}\text { Body mass index, (SD) } \\
\text { Ideal } 18.5 \text { to }<25 \mathrm{~kg} / \mathrm{m}^{2},(\%) \\
\text { Undernourished }<18.5 \mathrm{~kg} / \mathrm{m}^{2},(\%) \\
\text { Overweight } 25 \text { to }<30 \mathrm{~kg} / \mathrm{m}^{2},(\%) \\
\text { Obesity } \geq 30 \mathrm{~kg} / \mathrm{m}^{2},(\%) \\
\text { Waist circumference, }(\mathrm{SD}) \\
>102 \mathrm{~cm} \text { men }>88 \mathrm{~cm} \text { women }\end{array}$ & $\begin{array}{c}27.9 \pm 5.2 \\
27.6 \\
2.4 \\
38.8 \\
31.2 \\
93.6 \pm 12.7 \\
42.8\end{array}$ & $\begin{array}{c}27.4 \pm 5.0 \\
30.5 \\
3.2 \\
37.7 \\
28.6 \\
92.0 \pm 12.2 \\
38.7\end{array}$ & $\begin{array}{c}30.4 \pm 6.4^{\mathrm{a}} \\
19.2 \\
0.2^{\mathrm{a}} \\
40.0 \\
40.6 \\
101.3 \pm 13.7^{\mathrm{a}} \\
64.6^{\mathrm{a}}\end{array}$ & $\begin{array}{c}29.4 \pm 5.1^{\mathrm{a}} \\
18.0^{\mathrm{a}} \\
0.1^{\mathrm{a}} \\
43.5 \\
38.4^{\mathrm{a}} \\
97.4 \pm 11.8^{\mathrm{a}} \\
51.8^{\mathrm{a}}\end{array}$ \\
\hline $\begin{array}{l}\text { Waist/hip ratio, (SD) } \\
\quad \geq 0.90 \text { men } \geq 0.85 \text { women }\end{array}$ & $\begin{array}{c}0.9 \pm 0.1 \\
80.9 \\
\end{array}$ & $\begin{array}{c}0.9 \pm 0.1 \\
76.8 \\
\end{array}$ & $\begin{array}{c}1.0 \pm 0.1^{\mathrm{a}} \\
96.4^{\mathrm{a}} \\
\end{array}$ & $\begin{array}{c}1.0 \pm 0.1^{\mathrm{a}} \\
92.7^{\mathrm{a}} \\
\end{array}$ \\
\hline \multicolumn{5}{|l|}{ Biochemical characteristics } \\
\hline 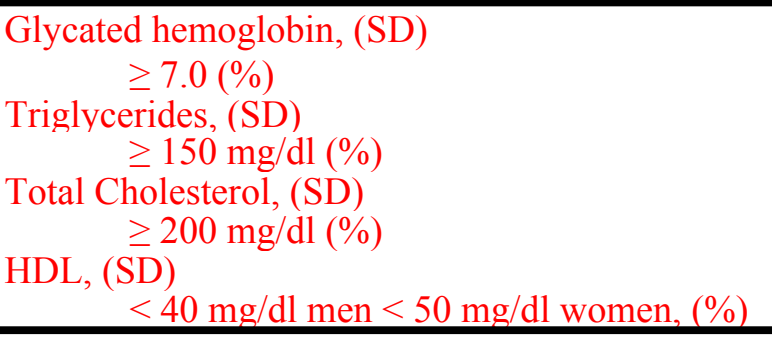 & $\begin{array}{c}6.1 \pm 1.3 \\
12.4 \\
181.2 \pm 113.4 \\
50.9 \\
191.2 \pm 41.1 \\
40.5 \\
46.9 \pm 14.4 \\
50.5 \\
\end{array}$ & $\begin{array}{c}5.6 \pm 0.4 \\
0.0 \\
171.8 \pm 100.3 \\
47.6 \\
193.7 \pm 39.6 \\
42.5 \\
47.8 \pm 14.4 \\
48.6 \\
\end{array}$ & $\begin{array}{c}7.8 \pm 1.9^{\mathrm{a}} \\
50.8 \\
242.8 \pm 176.5^{\mathrm{a}} \\
70.2^{\mathrm{a}} \\
199.7 \pm 42.7 \\
47.7 \\
42.4 \pm 15.3^{\mathrm{a}} \\
55.2 \\
\end{array}$ & $\begin{array}{c}7.5 \pm 2.1^{\mathrm{a}} \\
51.6 \\
195.7 \pm 124.4^{\mathrm{a}, \mathrm{b}} \\
56.8 \\
175.9 \pm 43.5^{\mathrm{a}, \mathrm{b}} \\
28.0^{\mathrm{a}, \mathrm{b}} \\
45.2 \pm 13.8^{\mathrm{a}} \\
56.9 \\
\end{array}$ \\
\hline
\end{tabular}

Means, standard deviation (SD) and proportions calculated considering sample weight. ${ }^{a}$ Significantly different from non-diabetics. ${ }^{\mathrm{b}}$ Significantly different from undiagnosed diabetics. 